\title{
SELECTED PROBLEMS OF PUBLIC EXPENDITURE PRO- GRAMMES ON REGIONAL LEVEL IN THE CZECH REPUBLIC
}

\author{
Markéta ŠUMPÍKOVÁ, Jana KRBOVÁ*, Jan PAVEL**, Juraj NEMEC***
}

\begin{abstract}
:
Efficiency, economy and effectiveness: outcomes and impacts of public expenditures are main issue especially from mid eighties, when massive changes in the public sector started, influencing both allocative and X-efficiency of public expenditures. Public expenditure programmes are implemented on many levels, from international to municipal, and in many different forms. In our paper, we decided to perform the analysis on the level of self-governing regions in the Czech Republic. We focus on the following dimensions of expenditure analysis: the scope and scale of allocative and regulatory public expenditure programmes in the region (from EU level programmes to regional); existing approaches used to analyse effectiveness of selected public expenditure programmes; impacts of public expenditure programmes on selected recipients (including capacity of recipients to apply for public resources - capacity to prepare projects to compete for public funds).
\end{abstract}

Keywords: public expenditure programme, self-governing regions, effectiveness, Czech Republic

JEL Classification: H50, H72, R58

\section{Introduction}

The state implements via a broad scale of public expenditure programmes several types of goals and objectives, connected with its main roles in the economy (see, for example, Stiglitz, 1989; Musgrave and Musgrave, 1997):

- allocative,

- (re)distributive,

- macroeconomic regulation.

The role of the state in the economy and society has been significantly growing from the middle of the last century, and most developed countries reached the ma-

*) University of Economics Prague, Faculty of Management, Jarošovská 1117/II, CZ - 37701 Jindřichův Hradec (e-mail: sumpik@fm.vse.cz; krbova@fm.vse.cz).

${ }^{\star *}$ ) University of Economics, 4, W. Churchill Sq., CZ - 13067 Prague 3 (e-mail: Pavel-Ja@ seznam.cz).

$\left.{ }^{\star \star \star}\right)$ University of Matej Bel, Cesta na amfiteáter 1, Banská Bystrica, Slovak Republic (e-mail: nemec @ financ.umb.sk).

${ }_{\star * \star *}$ ) The paper is based on an original research undertaken in 2002-2003 and supported by the Grant Agency of the Czech Republic, the project No. 402/03/1221. 
ximum relative level of public expenditures (in relation to gross domestic product GDP) in the eighties, the top in Sweden approaching $65 \%$ share of public spending in GPD (see Stiglitz, 1989).

With such a high relative level of public expenditures the state has become "overloaded" (see Coombes and Verheijen, 1997), the use of public power over-extended or misapplied, especially in the attempt to deliver goods and services that would be more efficiently provided in accordance with supply and demand determined by private economic interests, via market. In such a situation, the public expenditure analysis theory (with the basis developed already 10-15 years earlier, see, for example, Haveman and Margolis, 1970), and practice has become more and more important. Efficiency, economy and effectiveness: outcomes and impacts of public expenditures are now the main issues of public financial management, influencing both allocative and X-efficiency of public expenditures on all levels, from local to multinational.

In our paper, we decided to analyse selected issues of implementation and evaluation of public expenditure programmes on the example of one of the most developed transitional country - in the Czech Republic. We concentrated mainly on three important dimensions - the scope and scale of public expenditure programmes (with focus on regional development programmes), existing approaches used to analyse effectiveness of selected public expenditure programmes, and selected aspects of impacts of public expenditure programmes on funds' recipients (mainly the capacity of recipients to apply for public resources - capacity to prepare projects to compete for public funds).

\section{Regional Development Programmes in the Czech Republic}

The forms and ways of implementation of governmental policies focusing on execution of allocative, redistributive and regulative functions of the government represent almost infinity. To be able to provide some specific data on our topic we need first to define what part of this extremely large segment will be of our concern.

Taking into account the topic of our research grant provided by the Grant Agency of the Czech Republic, and the issue of data accessibility, we decided to focus on programmes from the group of so-called regional development programmes.

Regional development programmes focus mainly on macroeconomic, and in some cases also on microeconomic targets, and their main objective could be defined as the decrease of unemployment level and the increase of the per capita GDP in the region. In our analysis, we focus mainly on the following types of public expenditures:

- expenditures on active employment policies,

- expenditures to support capital investment programmes,

- expenditures supporting small and medium-sized entrepreneurship,

- infrastructure expenditures,

- expenditures supporting structural changes, including down-sizing of certain industries,

- to limited extend also certain expenditures connected with agriculture, but not programmes subsidising the production. 


\section{1 Problem of Current Regional Structure of the Czech Republic Con- nected with Use of Programme Funds}

The current situation in the territorial structure of the Czech Republic (CR) is as follows: try;

a) NUTS I - the highest level of region; in the case of the CR it is the whole coun-

b) NUTS II - in the Czech Republic so-called "Cohesion Regions". There are total 8 NUTS II regions in the country, some of the same as NUTS III regions (Prague, Central Bohemia, Moravia-Silesia), and others NUTS II consist of $2-3$ regions NUTS III;

c) NUTS III - within the boundaries of self-government regions. There are 14 NUTS III regions, some of them correspond with the previous socialistic territorial structure (e.g. Prague, Central Bohemia, etc.) and some of them newly emerged during the public administration reform (e.g. Vysočina, Pardubice);

d) NUTS IV - districts. There are 77 districts corresponding to the previous socialistic districts;

e) NUTS V - municipalities. There are more than 6 thousand municipalities. Many of them are too small to execute their responsibilities.

The Table 1 provides the comparison in size and number of inhabitants between regions NUTS II and NUTS III in the EU-15 states and the Czech Republic. It shows data including and excluding region Prague, because this region is abnormally smallsized with extremely high number of inhabitants and taking it into account might be misleading for our analysis. From the point of view of the size of the territory, the average size of Czech NUTS II regions (without Prague) and NUTS III regions (without Prague) is bigger in comparison with a size of regions in similar EU-15 states (but for NUTS II significantly bellow EU-15 average). From the point of view of the number of inhabitants the Czech regions NUTS II are below the EU-15 average, while NUTS III is above the EU-15 average.

Five from eight regions of cohesion (NUTS II) include $2-3$ self-government regions with different characteristics, priorities and strategies. We consider this situation as a potential generator of disputes, extra transaction costs, and limiting ability of action. The bodies of NUTS II are establishing very slowly and with many difficulties. Actually they are not in (full) operation yet, so we cannot collect data from them.

Table 1

Comparison between the EU and Czech Regions NUTS II and NUTS III

\begin{tabular}{|c|c|c|c|c|c|c|}
\hline \multirow[t]{2}{*}{ NUTS } & \multirow{2}{*}{$\begin{array}{l}\text { Expected } \\
\text { number of } \\
\text { inhabitants }\end{array}$} & \multicolumn{2}{|c|}{ Number of inhabitants of region } & \multicolumn{2}{|c|}{ Average size/territory of regions } & \multirow{2}{*}{$\begin{array}{l}\text { Size of regions in } \mathrm{EU} \\
\text { states similar to the } \mathrm{CR}\end{array}$} \\
\hline & & CR & EU average & CR & EU & \\
\hline II & 1-2 mill. & $\begin{array}{l}1.27 \text { mill; without } \\
\text { Prague: } 1.29 \text { mill. }\end{array}$ & 1.83 mill. & $\begin{array}{l}9,800 \mathrm{~km}^{2} \text {; without } \\
\text { Prague: } 11,200 \mathrm{~km}^{2}\end{array}$ & $23,000 \mathrm{~km}^{2}$ & $3-10,000 \mathrm{~km}^{2}$ \\
\hline III & $200-400,000$ & $\begin{array}{l}\text { 695,000; without } \\
\text { Prague: } 729,000\end{array}$ & 410,000 & $\begin{array}{l}5,600 \mathrm{~km}^{2} ; \text { without } \\
\text { Prague: } 6,100 \mathrm{~km}^{2}\end{array}$ & $5,400 \mathrm{~km}^{2}$ & $1-3,000 \mathrm{~km}^{2}$ \\
\hline
\end{tabular}

Source: Czech Statistical Office, Eurostat, 2003. 


\section{2 Regional Development Public Expenditure Programmes}

The public resources to finance regional development in the Czech Republic are provided by three main sources: state budget and state funds; self-government budgets and extra-budgetary means; EU funds (before accession pre-accession funds). The Table 2 provides overview of main programmes serving for regional development purposes, financed via state budget and state funds (or similar type of resources) and via EU pre-accessions funds and their scale in 2001 and 2002.

Table 2

Main Programmes for Regional Development Purposes in CR (in CZK mill.)

\begin{tabular}{|l|r|r|}
\hline Programme & 2001 & 2002 \\
\hline Active labour policies - grants & 1,972 & 1,420 \\
\hline Active labour policies - credits & 936 & 904 \\
\hline $\begin{array}{l}\text { Support of small and medium-sized enterprises via } \\
\text { Czech-Moravian Development Bank }\end{array}$ & 1,300 & 983 \\
\hline $\begin{array}{l}\text { Other programmes financed via Czech-Moravian } \\
\text { Development Bank }\end{array}$ & 1,571 & 1,001 \\
\hline $\begin{array}{l}\text { Support of small and medium-sized and enterprises via } \\
\text { the Ministry of Regional Development }\end{array}$ & 300 & 219 \\
\hline Down-sizing of mining industry & 4,017 & 3,280 \\
\hline Industrial development & 170 & 100 \\
\hline $\begin{array}{l}\text { Capital investment support via discount in corporate } \\
\text { income tax }\end{array}$ & 1,000 & 760 \\
\hline Tourism development programme & 269 & 200 \\
\hline Programme of rural renewal & 508 & 500 \\
\hline PHARE & 2,500 & 2,500 \\
\hline ISPA & 2,300 & 2,300 \\
\hline SAPARD & $70,175,000$ & $2,275,000$ \\
\hline Total direct subsidies & 0.81 & 0.65 \\
\hline Capital investment support via tax exemptions - estimate & 2,805 & 700 \\
\hline Subsidies total & 0.94 & 1.00 \\
\hline GDP & & 14,867 \\
\hline Direct subsidies/GDP & & 22,676 \\
\hline Subsidies total/GDP & & \\
\hline
\end{tabular}

Note: The exchange rate is approximate (30 CZK/EUR).

Source: State Budget 2001 and 2002.

Concerning EU finance (after accession the CR into the EU) it is necessary to stress that the Czech Republic has relatively complicated system of programming documents (already indicated). The highest level is represented by the "National De- 
velopment Plan", further elaborated in more detailed form by operational programmes (there are one "General Regional Operational Programme", four "Sectoral Operational Programmes" and one specific programming document for the Cohesion Fund on the central level). Furthermore, each self-government region has its own "Regional Development Programme", and finally each NUTS II prepares its "Regional Operational Programme". That means that the total scope of basic programming documentation is more than 10,000 pages long, including extra transaction costs connected with negotiations on the level of most NUTS II, comprising more selfgovernment regions. Taking into account that the decision on new territorial structure of the Czech Republic has been done only recently, more effective solutions were already available.

Programming documentation concerning the Czech regional policy financed from the national sources represents second parallel line of programming. As indicated, this line includes several different programming documents, like the "Regional Development Strategy", "State Programme of Regional Development", "Programme of the Rural Renewal", "Programme of the Tourism Development", "Programmes of the District's Development (for 77 districts), "Strategies (or Plans or Programmes) of the Municipal Development (prepared by many from more than 6,000 municipalities).

From this description it becomes obvious that the programming base for regional development is becoming to be really large system, creating certain, probably important transaction costs to operate such huge system. However, not transaction costs, but lack of co-ordination between different levels of programmes is the main problem.

\section{2. 1 EU Finance and Regional Development}

As already indicated, there were three main EU pre-accession sources, which could be used for regional development purposes, in the Czech Republic - PHARE, ISPA and SAPARD. ${ }^{1)}$ Tables $3-5$ highlight the allocation of resources via respective EU funds.

The main historic EU resource for the Czech Republic was the PHARE programme. Most of resources of this programme was allocated on the central level (about $75 \%$ ), and was used to prepare the country for EU memberships. Other approximately $20 \%$ was allocated for cross-border co-operation programmes, within the frames of PHARE-CBC. Regions were able to use during the operation of the programme more than EUR 385 mil.

ISPA was introduced for the Czech Republic much later than PHARE, and its funds were allocated (till May 2003) for 14 large capital investments projects, supporting directly or indirectly the regional development. Interesting example might be

1) For those not from EU region - the PHARE programme was the main channel for the European Union's financial and technical co-operation to help the countries of Central Europe to prepare for accession to the EU. Set up in 1989 to support reform in Poland and Hungary, the PHARE programme has been extended to include 10 partner countries from Central Europe, all of which had applied to the European Union, including the Czech Republic. Initially designed to help these countries in their transition towards democracy and a market economy, PHARE's role has gradually evolved. Since 1994, PHARE has been focused on supporting the ten applicant countries in their preparations for accession to the EU. The European Commission, which is the executive body of the European Union, is responsible for PHARE funds, in co-operation with the recipient governments. The ISPA programme provides finances for transport and environmental infrastructure projects that helped the partner countries to meet EU standards in the environmental sector and transport infrastructure. ISPA provided for investment backing of construction and reconstruction. The SAPARD programme helped candidate countries to cope with specific issues of the Common Agricultural Policy as well as with structural changes in individual agricultural sectors. 
project "Clean Bečva" (Bečva is the river in North-East of the country). The final recipient of resources is the Association of Municipalities of Vsetín region. The largest sum of funds was used in Olomouc self-government region, able to bid successfully for two transport projects (EUR 90 mill.) and two environmental projects (EUR 20 mill.).

Similarly to ISPA, also SAPARD was introduced much later than PHARE. The largest recipients of resources for agriculture and rural development are South-Moravia and South-Bohemia, where agriculture represents important part of economic activities.

The Table 3 shows planned and actual allocation of EU funds in the Czech Republic for the entire period of functioning of this form of EU support. The planned allocation is different from real allocation (because of amendments) and different from the scale of used funds (because of level of success to prepare projects). For example in 2000 the Czech Republic obtained extra EUR 23 mill., in 2001 extra EUR 8 mill., in 2002 EUR 25 mill. This sum does not include resources obtained from multinational programmes.

Table 3

Total Allocations of EU Funds for CR (in EUR mill.)

\begin{tabular}{|l|c|l|l|}
\hline & $\begin{array}{l}1995-1999 \\
\text { (maximum planned } \\
\text { resources per year) }\end{array}$ & $\begin{array}{l}2000-2002 \\
\text { (maximum planned } \\
\text { resources per year) }\end{array}$ & $\begin{array}{l}\text { Total allocations of EU funds for the } \\
\text { Czech Republic in years } \\
\text { 990 - 2001 (12 years of PHARE, } \\
2 \text { years of ISPA and SAPARD) }\end{array}$ \\
\hline PHARE & 69 & 79 & 841 \\
\hline ISPA & - & $57.2-83.2$ & 137 \\
\hline SAPARD & - & 22.1 & 44 \\
\hline Total & 69 & $158.3-184.3$ & 1,022 \\
\hline
\end{tabular}

Source: www.mvr.cz, 2003.

The main official Czech statistics does not show exactly what proportion of used EU funds is used for regional development, and what for other purposes. The Table 4 provides the structure of officially available data.

Table 4

The Structure of Use of EU Funds 1990 - 2001 (in EUR mill.)

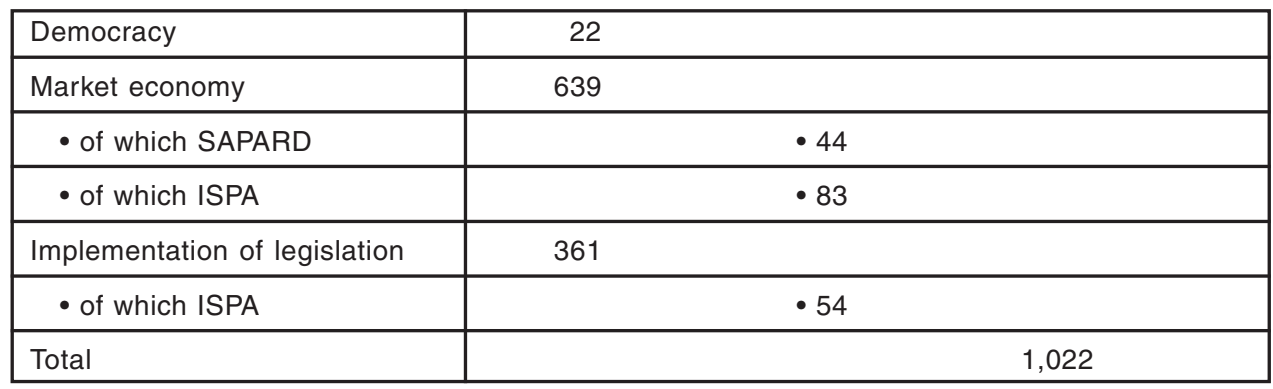

Source: www.evropska-unie.cz, 2003. 
There are also certain data available on allocation of EU resources used by the self-government regions of the Czech Republic (see Table 5). These data do not fully correspond with the mentioned distribution of funds (about $70 \%$ of PHARE for central administration) and probably re-allocate part of funds from central level to final recipients.

Table 5

The EU Funds for Regional Development 1991 - 2003 (in EUR mill.)

\begin{tabular}{|c|c|c|c|c|c|c|c|c|c|}
\hline NUTS II & Prague** & $\begin{array}{l}\text { Central } \\
\text { Bohemia** }\end{array}$ & $\begin{array}{l}\text { South } \\
\text {-West }\end{array}$ & $\begin{array}{l}\text { - In it } \\
\text { South } \\
\text { Bohemia }\end{array}$ & $\begin{array}{l}\text { - In it } \\
\text { Plzeň }\end{array}$ & $\begin{array}{l}\text { Nort- } \\
\text { West* }\end{array}$ & $\begin{array}{l}\text { North } \\
\text {-East }\end{array}$ & $\begin{array}{l}\text { - In it } \\
\text { Pardubice }\end{array}$ & $\begin{array}{l}- \text { In it } \\
\text { Hradec } \\
\text { Králové }\end{array}$ \\
\hline ISPA & 8.5 & 3.8 & 10.4 & 5 & 5.4 & 16.9 & 46.8 & 45 & - \\
\hline SAPARD & - & 7.6 & 8.2 & 4.1 & 4.1 & 3.1 & 7.8 & $2.6^{*}$ & $2.6^{*}$ \\
\hline Phare total & 4.9 & 0.3 & 35.6 & 17.8 & 17.8 & 188.4 & 42.7 & 9.4 & 5.6 \\
\hline Total & 13.4 & 11.7 & 54.2 & 26.9 & 27.3 & 208.4 & 97.3 & 57 & 8.2 \\
\hline
\end{tabular}

\begin{tabular}{|l|c|c|c|c|c|l|c|c|}
\hline NUTS II & $\begin{array}{l}\bullet \\
\text { Liberec }\end{array}$ & $\begin{array}{l}\text { South } \\
\text {-East }\end{array}$ & $\begin{array}{l}\bullet \text { In it } \\
\text { Vysočina }\end{array}$ & $\begin{array}{l}\text { - In it } \\
\text { South } \\
\text { Moravia }\end{array}$ & $\begin{array}{l}\text { Mid } \\
\text { Moravia }\end{array}$ & $\begin{array}{l}\text { In it } \\
\text { Olomouc }\end{array}$ & $\begin{array}{l}\text { In it } \\
\text { Zlín }\end{array}$ & $\begin{array}{l}\text { Moravia- } \\
\text { Silesia** }^{* *}\end{array}$ \\
\hline ISPA & 1.6 & 60.8 & 43 & 18 & 143.8 & 111.5 & 32 & 73.9 \\
\hline SAPARD & $2.6^{*}$ & 11.2 & 2.3 & 9 & 6.7 & $3.35^{*}$ & $3.35^{*}$ & 3.7 \\
\hline Phare total & 27.8 & 80.7 & 11.8 & 68.9 & 34.4 & 30.7 & 3.7 & 68.9 \\
\hline Total & 32 & 152.7 & 57.1 & 95.9 & 184.9 & 145.55 & 39.05 & 146.5 \\
\hline
\end{tabular}

Note: Items labelled with $\left(^{*}\right)$ data are available only for NUTS II, $\left({ }^{* *}\right)$ NUTS II = NUTS III. Source: www.evropska-unie.cz, 2003.

\section{2. 2 National Financial Resources for Regional Development}

The national Czech regional development resources represent funds from the state budget and similar sources, plus local financial resources (self-government regions and other bodies). State financial support for regional development is declared as a complement to regional own sources and it is not obligatory. The potential recipients are self-government regions, association of municipalities, municipalities and their legal bodies, business entrepreneurs, non-governmental and non-profit organizations and other legal bodies. There are different forms of support, like direct subsidies, credits with favoured interest rate, returnable financial support, including non-financial forms (gifts, technical assistance, consultations, etc.).

As indicated, the main document for the implementation the regional policy on the county level is the "Regional Development Programme" (RDP). The document provides the analysis of the current situation, SWOT analysis, sets the strategic goals, priorities, provisions, activities, implementation structure and system of financing and overviews the financial sources including the public and private financial sources.

Self-government regions can use three ways of supporting regional development by their own resources:

- grant scheme, 
- development fund, ${ }^{2)}$

- allocation of finance to and by respective departments of self-government regional office (e.g. education, health, infrastructure, environment, regional development, etc.).

In accordance with the Act No. 250/2000 Coll., on Regional Budgetary Rules and the Act No. 248/2000 Coll., on Support of Regional Development counties may establish, a Regional Development Fund. In year 2003 only 3 from 14 self-government regions used this form (see Table 6), and other 2 counties established fund in 2003 and gradually allocate the financial sources into it. Some counties think about the fund establishment from the 2004 and some of them have no a clear vision yet, and are looking for the political agreement.

Selection of projects applying for money from this Fund was performed according to the Principles for Project Selection and Financial Support. Using fund for distributing money leads to the higher transparency, enables monitoring of efficiency, economy and effectiveness of public expenditure and is a tool for implementation of EU standards into practice of Czech public administration. Average financial support of RDP activities via Fund scheme per head is EUR 5.

Grant scheme is a more frequently used method (5 self-government regions). This method is based on distribution of financial sources and competence for pro-

Table 6

Forms of Financing the Regional Activities on the Self-government Region Level in 2003 (programmes of regional development and their financing in 2003)

\begin{tabular}{|l|c|c|c|}
\hline \multirow{2}{*}{ Item } & \multicolumn{3}{|c|}{ Form of financing } \\
\cline { 2 - 4 } & Development fund & Grant scheme & $\begin{array}{c}\text { Allocation to and } \\
\text { by departments }\end{array}$ \\
\hline Number of counties (total 14) & 3 & 5 & 6 \\
\hline Number of inhabitants & $1,887,094$ & $3,488,109$ & $4,831,233$ \\
\hline Revenues in thousands EUR & 482,217 & 903,821 & $1,356,854$ \\
\hline Expenses in thousands EUR & 482,217 & 906,902 & $1,555,386$ \\
\hline Balance in thousands EUR & 0.00 & -3081 & $-198,532$ \\
\hline $\begin{array}{l}\text { Expenses on development activities in } \\
\text { accordance with RDP in thousand EUR }\end{array}$ & 9,338 & 9,632 & n.a. \\
\hline $\begin{array}{l}\text { Development activities in accordance } \\
\text { with RDP in \% from the total expenses }\end{array}$ & 1.94 & 1.06 & n.a. \\
\hline $\begin{array}{l}\text { Average expenses from county's } \\
\text { budget per head in EUR }\end{array}$ & 256 & 260 & 322 \\
\hline $\begin{array}{l}\text { Average financial support of RDP } \\
\text { activities per head in EUR }\end{array}$ & 5 & 2.8 & n.a. \\
\hline
\end{tabular}

Note: The exchange rate is approximate (30 CZK/EUR).

Source: Budgets of counties, interviews, own calculations, $2002-2003$.

2) Decision about distribution the financial sources is made by body of Fund with agreement of county's Board of Representatives. The decision is driven by Status of Fund and by Principles for subsidy from the Fund. 
ject selection lies among departments of self-government office. Each self-government region, or in the extreme case each department of its office publishes own Principles for Project Selection and Financial Support. The final decision is on selfgovernment region assembly, and shall be in accordance with the RDP. The linkages between allocation of sources and priorities, provisions and activities of RDP are relatively clear. The average financial support of RDP activities via grants scheme per head is EUR 2.8.

The third form (allocation to and by respective self-government region office departments) is very similar to the second one, and is used by 6 self-government regions. The difference is that in this case resources are allocated to the department (in the first one department selects), and become part of its budget. Such arrangements are non-transparent, and cause decoding, which subsidy is for RDP activities and which is for non-Programme activities very difficult.

The Table 6 illustrates the differences in approach to the support of regional development.

Already the Table 2 indicated that there are different types of public expenditure programmes to finance the regional development by the state budget and similar resources. In the Table 7 we provide example of one district, and its external state funds based development resources, compared with self-administration and EU funds.

Table 7

The Structure of Public Expenditure Programmes in the District Jindřichův Hradec according to Resources (in thousands CZK)

\begin{tabular}{|l|r|r|r|r|r|r|}
\hline & \multicolumn{1}{|c|}{2000} & \multicolumn{1}{|c|}{2001} & \multicolumn{1}{c|}{ Total } & in \% \\
\hline A. State budget resources & & & & & & \\
\hline $\begin{array}{l}\text { Ministry of Industry } \\
\text { and Trade }\end{array}$ & 2,200 & 0 & 0 & 0 & 2,200 & 40.75 \\
\hline $\begin{array}{l}\text { Ministry for Regional } \\
\text { Development }\end{array}$ & & 475 & 420 & 154 & 1,049 & 19.43 \\
\hline B. State funds & 0 & 0 & 0 & 0 & 0 & 0.00 \\
\hline C: Self-government region & & & & 500 & 500 & 9.26 \\
\hline D: CCCR & 750 & 300 & 300 & 300 & 1,650 & 30.56 \\
\hline Total national resources & 2,950 & 775 & 720 & 954 & 5,399 & 100.00 \\
\hline E. EU funds & & & & & & \\
\hline SAPARD & 0 & 0 & 0 & 8470 & 8,470 & 100.00 \\
\hline
\end{tabular}

Note: The exchange rate is approximate (30 CZK/EUR).

Source: Own calculations on the base of interviews and questionnaires, 2003.

\section{Selected Current Approaches to Evaluate Pub- Iic Expenditure Programmes in the Czech Re- public}

The analysis in the previous subchapter clearly shows that there are really very many types of public expenditure programmes implemented in the Czech Republic 
(we just presented some of them in the area of regional development). ${ }^{3)}$ According to the EU standard any public expenditure programme shall be ex-ante and ex-post evaluated. In the following text we provide basic requirements for such analysis representing the introduction of a value for money type of audit in the conditions of Central and Eastern Europe. Such audit shall check if the organization (in our case an expenditure programme) conducts its financial affairs in an economic, effective and efficient manner, and it is the reaction to the deficiencies of the probity audit, which ensures to a great extent that processes are run correctly, but says nothing about real results.

Value for money (best value, or other names) audit deals with the following main concepts and topics (see Wright and Nemec, 2002). Economy, concern with the conversion of inputs to outputs and attempting to ensure that minimum inputs will be used to achieve defined outputs. Efficiency, analysing the ratio between inputs and outputs. Effectiveness, aimed at ensuring that efficiently produced outputs are directed toward achieving the desired outcomes. Inputs: it represents all resources used to produce expected outputs, outcomes and impacts. Outputs: it represents goods and services delivered from inputs. Outputs are usually measured by quantitative non-monetary figures (number of surgical operations). Outcomes: it represents a more difficult concept and are used to measure what was really achieved. By this, outcomes include both quantitative and qualitative dimension (number of surgical operations and their success). Compared to inputs and outputs, outcomes are very difficult to measure especially if we want to calculate them in monetary terms, for example, to conduct social cost-benefit analysis. Impacts: it represents the most complex measure to evaluate real achievements over a long-term period such as the decrease of unemployment in a respective region as the result of some macroeconomic programme.

Willing to improve the quality of planning and programming and reinforcing the relevance of the strategies they contain, the EU Commission asks for an assessment of the extent to which plans or programmes are an appropriate means of addressing the issues, are part of a coherent strategy with well-defined priorities and objectives, have appropriately quantified objectives whose achievement is capable of monitoring and evaluation and propose adequate implementation and monitoring arrangements.

The overall purpose of evaluations is to provide the Commission with a degree of reassurance that the plans and programmes being submitted have been the subject of external scrutiny, which indicates that they are an appropriate response to the economic development needs of the area covered, proposing to put in place efficient and transparent decision making and management mechanisms, and expressed in terms which are capable of monitoring and evaluation.

The evaluation shall cover at least following topics: analysis of previous evaluation results and SWOT analysis; assessment of the rationale and overall consistency of the strategy; quantification of objectives; evaluation of expected socio-economic impacts and justification of the policy and financial resources allocation; quality of the implementation and monitoring mechanisms; linkages to the strategy, goals and priorities; consideration of horizontal themes (employment, sustainable growth, equality of opportunities, ICT tools); strategic environmental assessment (SEA, on the level of national or sectoral programmes or environmental impact assessment, EIA, on the level of projects).

3) Our research will continue, and one of its main goals will be to prepare more comprehensive picture on scope and scale of public expenditure programmes in selected region. 
In our research we tried to obtain data on the processes of evaluation of public expenditure programmes on regional level in the Czech Republic. The results of this analysis are very disappointing. For most (except of EU funded programmes, where such analysis is now compulsory) regional public expenditure programmes neither ex-ante, nor ex-post analysis was performed (the situation would change only now, as the result of adoption new legislation on public financial control) - these findings fully support heavy criticism of the quality of public financial control and audit in Central and Eastern Europe, provided for example by Wright and Nemec (2002).

There are only few programmes, where some attempts to evaluate them are realised. We provide 2 selected examples of them. The programme supporting development of small and medium-sized enterprises was evaluated for impacts by the following indicators (see Ministry of Industry and Trade, 2003): total amount of resources allocated via the programme per year; number of newly created jobs and resources per newly created jobs 2001 . This programme is not, however, evaluated on basis of multifactor correlation, to be able to assess an influence of other factors

Table 8

Correlation between Needs (expressed by level of unemployment) and Level of Resources Allocated via Public Expenditure Programmes for the Region

\begin{tabular}{|l|c|c|c|c|c|}
\hline $\begin{array}{l}\text { Self-government } \\
\text { region }\end{array}$ & $\begin{array}{c}\text { Level of } \\
\text { unemployment } \\
\text { in 2002 (\%) }\end{array}$ & $\begin{array}{c}\text { Allocated } \\
\text { resources for } \\
\text { SME support } \\
\text { in 2002 } \\
\text { (in thousands } \\
\text { CZK) }\end{array}$ & $\begin{array}{c}\text { Allocated } \\
\text { resources for } \\
\text { active } \\
\text { unemployment } \\
\text { policies } \\
\text { in 2002 (in } \\
\text { thousands CZK) }\end{array}$ & $\begin{array}{c}\text { Capital } \\
\text { investment } \\
\text { support } \\
\text { programme } \\
\text { before new law } \\
\text { (in thousands } \\
\text { CZK) }\end{array}$ & $\begin{array}{c}\text { Capital } \\
\text { investment } \\
\text { support } \\
\text { programme } \\
\text { after new law } \\
\text { (in thousands } \\
\text { CZK) }\end{array}$ \\
\hline Prague & 3.6 & 0 & 52,589 & 57,600 & 31,531 \\
\hline Mid-Bohemia & 6.8 & 32,700 & 155,995 & 663,945 & 689,068 \\
\hline South-Bohemia & 6.0 & 18,800 & 161,216 & 0 & 121,379 \\
\hline Plzeň & 6.6 & 6,700 & 96,354 & 72,650 & 77,705 \\
\hline Karlovy Vary & 9.3 & 3,400 & 47,411 & 0 & 108,384 \\
\hline Ústí nad Labem & 16.3 & 61,300 & 637,227 & 133,800 & 955,947 \\
\hline Liberec & 7.9 & 3,900 & 85,589 & 61,640 & 158,912 \\
\hline Hradec Králové & 6.6 & 9,300 & 69,294 & 46,470 & 202,940 \\
\hline Pardubice & 7.9 & 20,300 & 141,349 & 81,000 & 208,642 \\
\hline Vysočina & 7.4 & 9,200 & 137,558 & 11,000 & 371,535 \\
\hline South-Moravia & 10.2 & 15,000 & 261,064 & 96,950 & 159,443 \\
\hline Olomouc & 11.6 & 18,400 & 183,583 & 751,283 & 131,021 \\
\hline Zlín & 9.2 & 9,600 & 157,324 & 69,400 & 44,996 \\
\hline Moravia-Silesia & 15.2 & 94,300 & 459,866 & 59,500 & 121,490 \\
\hline Correlation & & 0.78 & 0.87 & 0.13 & 0.41 \\
\hline
\end{tabular}

Note: the exchange rate is approximate (30 CZK/EUR).

Source: Czech Statistical Office Analysis of the Employment and Unemployment in 2002; Ministry of Labour and Social Affairs of the CR, 2003; Report on the Small-medium Enterprises Sector Development in 2002, Ministry of Industry and Trade of the CR, 2003; Evaluation of Capital Investment Support Projects, Ministry of Industry and Trade of the CR, 2003. 
that may stay behind. The second example is a state unemployment policy, which is assessed by the following indicators (see Ministry of Labour and Social Affairs, 2002): costs of the programme; newly created jobs such as the number of public utility jobs places (programme creates new jobs on municipal level, to deliver certain basic mainly manual/non-skilled services, like cleaning), social jobs, temporary places for graduates and protected jobs; rate costs per a job.

More sophisticated approach was used to evaluate effectiveness of regional development programmes, focusing on minimising regional differences. In this case, the relation between the level of resources allocated and the unemployment rate was statistically analysed (see Table 8 ), to be able to assess whether decisions on allocation of funds have been done properly. Four programmes were analysed, as follows:

- programme supporting small and medium-sized entrepreneurship,

- active labour market policies,

- capital investment support programme in the regime before adopting the Act No. 72/2000 Coll.,

- capital investment support programme in the regime after adopting the Act No. 72/2000 Coll.

The results show that in first two cases, resources are used mainly in regions with high need. Opposite is true for capital investment programmes, especially before adopting new legislation.

The transitional country were with very limited amount of resources available for public expenditure programmes, and with the need to restructure the pattern of public expenditure (the Czech Republic has been fighting with too large yearly deficits of public budgets for period of the last 5 years, far above Maastricht criteria, and adopting new relevant measures - Public Finance Reform Legislative Package). In the old regime, any public resources allocation was centrally decided on the base of pure political reasons. In spite of this, 14 years has gone after democratic changes and the country joined the EU in 2004 without sufficient experience, skills, and motivation to realise comprehensive public expenditure evaluation pertains.

\section{Impacts of Public Expenditure Programmes on Recipients}

In our research we plan (as the last phase) to try to assess also impacts of allocating public money by public expenditure programmes on behaviour of all kinds of recipients. This issue represents crucial moment concerning effectiveness of public expenditure programmes.

Public expenditure programmes (except of some transfer payments) cannot serve just as a "pillow" to help, and again and again to help (at least not in long-term perspective). They shall provide temporary needed support to overcome specific problems of respective subject, "starting injections" to achieve sustainability. This dimension will be one important part of our future research, and today no data are available on it.

There is also second dimension, we already started to analyse it in this part of the research. As indicated, public sector financing changes on all levels from classic system of subjective allocation of grants to planned and programmed system. Thus the capacity of any subject on recipient side of the "market" is also a crucial factor. The typical example of this problem were difficulties of all transitional countries in allocation of EU pre-accession programmes, in preparation of enough number of well developed projects to compete for programme allocated money (in 2003, 
according to the evaluation of the EU Commission, the weakest pre-accession country from the group that joined the EU in 2004 was Slovakia).

As indicated, recipients of programme allocated public expenditure programmes resources might be many types of legal bodies, from business corporations, via nonprofit bodies, to self-government structures. Already existing data indicate that none of these segments is already fully prepared for programme/project allocation (even the system of advising and consultation for this area is just emerging). Figure below provides some general data on success concerning preparation of projects. Selected Data on Success Concerning Preparation of Projects. The Evaluation of Suc-
cess in Submitting of Projects: SAPARD

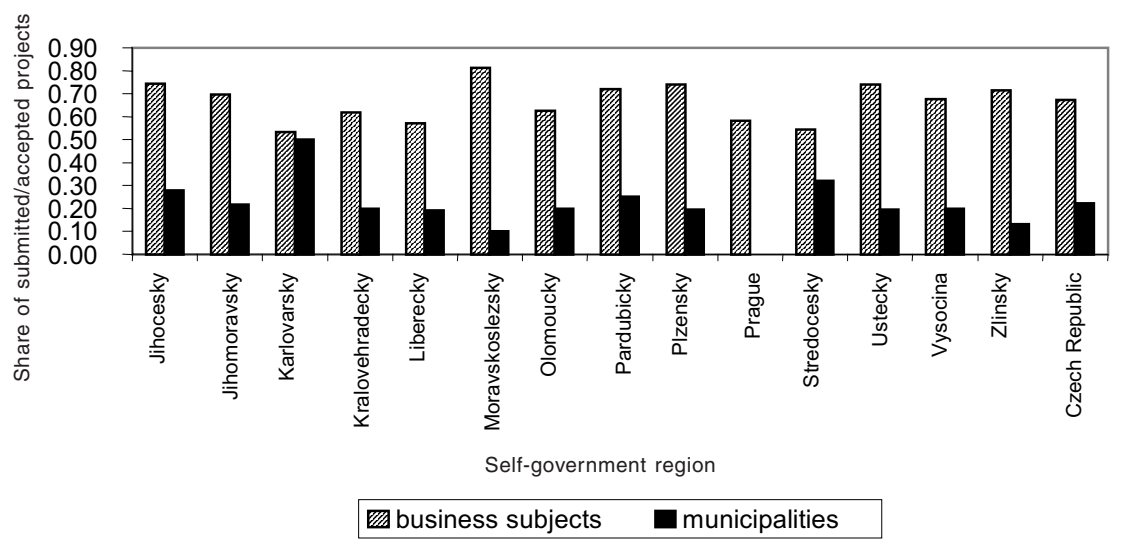

Source: Sapard Agency, 2002 - 2003, own calculations.

As indicated by figure, relatively critical situation concerning preparedness to create and submit projects is on the level of municipalities. In the following text we will highlight one dimension of this problem.

As indicated, the base for programme allocation of regional development resources today is the Regional Development Programmes. The research performed in South-Bohemia region by the team clearly indicates that the level of co-operation between self-government regions and municipalities and "micro-regions" is still very limited, some smaller municipalities even do not have (more or less) any information about the process/influence on the process of preparing this Programme. The quality of communication between municipalities/micro-regions and the regional government is very limited (see Table 9). Some municipalities still feel that the regional development is not their issue (about $15 \%$ ).

The purposes of recent not fully satisfactory situation are on both sides. No doubt, self-government regions that function only for two years, need more time to create effective experience in this (and all other) area. However, there are also important capacity problems of the level of municipalities. We have already mentioned that there are more than 6,000 municipalities in the Czech Republic, very many of them with less than 1,000 inhabitants (the territorial structure of the Czech Republic is the most fragmented in the Central Europe - see Horvath, 2000).

Municipalities with limited number of inhabitants usually have neither administrative, nor professional, nor financial capacity to prepare good quality projects to bid for any programme based public funds (see Horvath, 2000). As there is no chance to amalgamate municipalities by any politico-administrative order in the Czech Re- 
Table 9

Co-operation between Self-government Regions and Municipalities or Micro-regions in Preparation of Regional Development Programme

\begin{tabular}{|c|c|c|c|c|c|c|c|}
\hline \multirow[t]{2}{*}{ Question } & \multicolumn{3}{|c|}{ Municipalities } & \multicolumn{3}{|c|}{ Micro-regions } & \multirow[t]{2}{*}{ Note } \\
\hline & Evaluation & Number & $\%$ & Evaluation & Number & $\%$ & \\
\hline \multirow{2}{*}{$\begin{array}{l}\text { 1. Are you } \\
\text { involved into the } \\
\text { preparation of } \\
\text { RDP? }\end{array}$} & Yes & 19 & 52.7 & Yes & 2 & 33.0 & \\
\hline & No & 17 & 47.3 & No & 4 & 67.0 & \\
\hline \multirow{3}{*}{$\begin{array}{l}\text { 2. Level of } \\
\text { involvement into } \\
\text { the preparation } \\
\text { of RDP }\end{array}$} & $0-3$ & 21 & 58.3 & 0 & 3 & 50.0 & \multirow{3}{*}{$\begin{array}{l}0=\text { no } \\
\text { participation }\end{array}$} \\
\hline & $4-6$ & 11 & 30.6 & 1 & 2 & 33.0 & \\
\hline & $7-10$ & 4 & 11.0 & 8 & 1 & 17.0 & \\
\hline \multirow{2}{*}{$\begin{array}{l}\text { 3. Level of } \\
\text { information } \\
\text { provided during } \\
\text { the preparation } \\
\text { of RDP }\end{array}$} & Enough info & 16 & 44.4 & Enough info & 5 & 83.3 & \\
\hline & Lack of info & 20 & 56.6 & Lack of info & 1 & 16.7 & \\
\hline \multirow{3}{*}{$\begin{array}{l}\text { 4. Does the } \\
\text { region provide } \\
\text { the information } \\
\text { concerning RDP } \\
\text { as the standard } \\
\text { service? }\end{array}$} & Yes & 12 & 33.3 & Yes & 0 & 0.0 & \multirow{3}{*}{$\begin{array}{l}\text { Other resources } \\
\text { indicated were: } \\
\text { Internet, own } \\
\text { info, discussi- } \\
\text { ons, and } \\
\text { journals }\end{array}$} \\
\hline & No & 7 & 19.4 & No & 4 & 67.0 & \\
\hline & Partly & 17 & 47.2 & Partly & 2 & 33.0 & \\
\hline \multirow{3}{*}{$\begin{array}{l}\text { 5. How do you } \\
\text { see future level } \\
\text { of your } \\
\text { involvement into } \\
\text { the preparation } \\
\text { of RDP? }\end{array}$} & Shall be higher & 17 & 47.2 & Shall be higher & 5 & 83.3 & \\
\hline & Is already OK & 18 & 50.0 & Is already OK & 1 & 16.7 & \\
\hline & Shall be lower & 1 & 2.8 & Shall be lower & 0 & 0.0 & \\
\hline \multirow{3}{*}{$\begin{array}{l}\text { 6. Are your } \\
\text { comments } \\
\text { incorporated? }\end{array}$} & Fully & 9 & 25.0 & Fully & 0 & & \\
\hline & Partly & 22 & 61.1 & Partly & 5 & 83.3 & \\
\hline & Not at all & 1 & 2.8 & Not at all & 0 & & \\
\hline \multirow{4}{*}{$\begin{array}{l}\text { 7. Quality of co- } \\
\text { operation with } \\
\text { the self- } \\
\text { government } \\
\text { region }\end{array}$} & Fully OK & 7 & 19.4 & Fully OK & 0 & 0.0 & \\
\hline & Partly OK & 19 & 52.8 & Partly OK & 2 & 33.0 & \\
\hline & Partly insufficient & 8 & 22.2 & Partly insufficient & 4 & 67.0 & \\
\hline & Fully insufficient & 1 & 2.8 & Fully insufficient & 0 & 0.0 & \\
\hline
\end{tabular}

Source: Own research, 2003.

public, the only way is municipal co-operation (municipal associations) or public/private/civil sector mix co-operation.

Programme allocation is one of the important motives to associate, and more and more different types of associations already emerged in the Czech Republic - typical are micro-regions (respecting that in most cases programme targets are related to larger than municipal territory), associations of municipalities, creation of joint 
administrative bodies of more municipalities for execution of specific tasks, contracts, etc.

*

Public expenditure programmes allocate resources withdrawn from the private sector to fulfil specific tasks of the government. Because of this nature, it is necessary to prove that the use of public funds serves to purposes of efficiency and effectiveness (value for money), and delivers important impacts and outcomes.

The Czech Republic does not represent exemption, and a comprehensive set of public expenditure programmes is implemented for allocative, redistributive and macro-economic purposes. In our paper, we examined selected issues connected with this system.

In spite of the fact that, our research is still in its early phase, it is possible to confirm two crucial facts. The level and quality of evaluation of public expenditure in the Czech Republic is very limited and shall be improved. Except for recent changes pushed by adopting of EU principles, most of public expenditures are not regularly ex-ante (effectiveness) and ex-post (outcomes, value for money based) evaluated. The impacts of public expenditures on behaviour of recipients are also not regularly monitored. A large part of recipients, mainly smaller municipalities are not prepared, and do not have administrative, professional and financial capacity to prepare effective projects to bid for programme allocated funds.

References

Act No. 128/2000 Coll., on Municipalities.

Act No. 129/2000 Coll., on Self-Government Regions.

Act No. 248/2000 Coll., on Support of Regional Development.

Act No. 25/2000 Coll., on Rules of Regional Budgeting.

Bailey, S. J. (1999), Local Government Economics: Principles and Practice. Basingstoke: MacMilIan.

(1995), Public Sector Economics. Basingstoke: MacMillan.

Coombes, D., Verheijen, T. (eds.) (1997), "Public Management Reform: Comparative Experiences from East and West". Brussels, European Commission.

DHV CR (2000), "Regional Development Programme - Methodical Guide”. (in Czech). Prague, DHV CR, Ltd.

EC (2001), "European Governance: a White Paper". Brussels, European Commission.

Hamerníková, B., Kubátová, K. (1999), Public Finance (in Czech). Prague: Eurolex Bohemia.

Haveman, R. H., Margolis, J. (1983), Public Expenditures and Policy Analysis. Boston: Houghton Mifflin College.

Horvath, T. M. (2000), Decentralisation: Experiments and Reforms. Budapest: OSI LGI.

MITCR (2003), "Report on the SME Sector Development in the Year 2002". Prague, Ministry of Industry and Trade of the Czech Republic.

(2003), "Evaluation of Capital Investment Support Projects, CZ". Prague, Ministry of Industry and Trade of the Czech Republic.

MLSACR (2002), "Analysis of the Employment and Unemployment in Year 2002". Prague, Ministry of Labour and Social Affairs of the Czech Republic.

Musgrave, R. A., Musgrave, P. (1997), Public Finance (in Czech). Prague: Grada Publishing.

Nemec, J., Pavel, J. (2001), "Public Sector Management" (in Czech). Jindřichův Hradec, University of Economics, Prague.

Nemec, J., Wright, G. (eds.) (1997), Public Finance: Theory and Practice in Central European Transition. Bratislava: NISPAcee.

Niskanen, W. A. (1971), Bureaucracy and Representative Government. Chicago: Aldine.

Ochrana, F. (1999), Public Projects and Public Procurement. Prague: CODEX Bohemia. 
Orviská, M. et al. (1999), “Economics and Financing of Public Sector” (in Slovak). Banská Bystrica, FF UMB.

Pollitt, Ch., Bouckaert, G. (2004), Public Management Reform. Oxford: Oxford University Press. Prančl, K. (2000), "Support of the Regional Development in the Czech Republic" (in Czech). Prague, Ministry of Regional Development of the CR.

Stiglitz, J. E. (1997), Economics of the Public Sector (in Czech). Prague: Grada Publishing.

Šumpíková, M., Potluka, O., Krbová, J. (2002), "Support of the Regional and Bussiness Enterprises' Activities from the Public Expenditure Programmes in the Regional and Structural Policy Framework" (in Czech). Banská Bystrica, University of Matej Bel Press.

Šumpíková, M., Potluka, O. (2002), "Theory and Practice of the Implementation of the EU Funds in the Czech Republic" (in Czech). Prague, International conference proceedings.

Wright, G., Nemec, J. (2003), Public Management (in Czech). Prague: Ekopress.

www.cso.cz

www.europe.eu.int

www.evropska-unie.cz

www.kraje.cz

www.mmr.cz

www.mvcr.cz

www.mpsv.cz

www.mpo.cz 